\title{
A Study on Anxiety Depression and Coping Strategies between West Bengal and Karnataka All India Inter University Male Athletes
}

\author{
Dr. Sandip Sankar Ghosh ${ }^{1 *}$, Mr. Anantarup Sen Sarma ${ }^{2}$ \\ ${ }^{I}$ Assistant Professors, University of Kalyani, Kalyani, Nadia-741235, West Bengal, India \\ ${ }^{2}$ Senior Research Scholar, University of Kalyani, Kalyani, Nadia-741235, West Bengal, India
}

*Corresponding Author: Dr. Sandip Sankar Ghosh, Assistant Professors, University of Kalyani, Kalyani, Nadia-741235, West Bengal, India

\begin{abstract}
:
Objective: The present study was aimed to investigate the sports competition anxiety, general anxiety (state anxiety and trait anxiety), depression and coping strategies among All India Inter University male athletes.

Methods: For the purpose of the study the investigators collected data from the 79th All India Inter University athletics championship held at Mangalore University by applying four different questionnaires. Twenty Six $(N=26)$ male athletes were selected and divided into two groups (13 from West Bengal and 13from Karnataka). Data were collected through Random sampling method by applying Sport Competition Anxiety Test (SCAT) developed by Rainer Martens in (1977), General Anxiety were measured through State-Trait Anxiety Inventory by Charles D. Spielberger (1977). Coping strategies were measured through Coping Strategy Scale developed by Srivastava, A. K. (2001). Depression was measured through a questionnaire developed \& standardized by Mishra O. P. et al. published by Agra Psychological cell Agra (U.P.).
\end{abstract}

Statistics: Mean and Standard Deviation of each variable were calculated. For comparison of the variables between the groups of subject statistical t-test was applied.

Result: Results revealed that the Bengali athletes were significantly higher in sports competition anxiety and General Trait Anxiety than the athletes of Karnataka. On the other hand no significant difference was found in Depression, Coping Strategies and General State Anxiety between the male athletes of West Bengal and Karnataka.

Conclusion: In terms of sports competition anxiety and General Trait Anxiety the athletes of Karnataka found better than their West Bengal counter parts. But there is no such difference found in Depression, Coping Strategies and General State Anxiety between them.

Keywords: Sports Competitive Anxiety (SCAT), General Anxiety, Coping Strategies, and Depression

\section{INTRODUCTION}

In the games and sports, psychological and physiological factors play an important role in determining the performance level (Grange \& Kerr, 2010; Schilling \& Hyashi, 2001). It has been recognized for many years that psychological factors, in particular anxiety, Depression and Coping strategies play an important role in competition. (Lizuka, 2005) observed as a result of his study that many factors, such as expectations, perfectionism, fear of failure, lack of confidence include feelings of anxiety in athletes. Those athletes, who experience high levels of anxiety, may fall sick, muscle tension, show aggressive behaviours face sleeping problems, low self- confidence and drop out of sport (Cox, 2010; Weinberg \& Gould, 2010; Abel \& Larkin, 1990). There is sufficient evidence from retrospective studies to suggest that that a number of psychological skill may contribute to peak performance.

According to Kumar et al - an individual feels mentally disturbed, he is said to be an anxiety mood. As for as anxiety in the field of physical education and sports activities are concerned, it is said that anxiety is most common in competitive sports environment. According to Robinson et all- anxiety and sports are deeply related with each other. He further stated that anxiety is not always bad but it can help the players in focusing and alerting in performing their actions. While participating in various sports activities, it observed that the participants get anxious. 
Depression: According to National Institute of Health (ICMR 2007). Genetics and external stresses are common causes of depression. Regardless of how physically fit an athlete is, genetics or chemical imbalance may influence the development of depression. Individual and personal sports create a high pressure environment that focuses on winning and achieving progress. Setbacks, whether because of a loss or an injury, may challenge an athlete, esteem and feelings of self worth and contribute to the development of depression.

Coping strategies: coping involves a personal response on the part of the athlete to address the stress response. The athlete feels anxious in competitive situation and traits to use personal coping resources to reduce anxiety. When an athlete uses a stress management technique or any other cognitive or behavioural intervention; this is form of coping.

\subsection{Purpose of the study}

- To find out the difference between West Bengal and Karnataka all India male athletes in case of sports competition anxiety and general anxiety.

- To find out the difference between West Bengal and Karnataka all India male athletes in case depression.

- To find out the difference between West Bengal and Karnataka all India male athletes in case coping strategies.

\section{Methods \& MATERials}

\subsection{Selection of the Subjects}

A total of twenty six $(\mathrm{N}=26)$ male all India Inter University athletes from the 79th All India Inter University Athletics Championship held at Mangalore University are selected from West Bengal (13 subjects) and Karnataka (13subjects) state in simple random sampling method for the present study. The age range of the subjects was 18 to 25 .

\subsection{Tools used for the Study}

- Sports competition anxiety questionnaire by Marten 1977.

- General Anxiety was measured through State-Trait Anxiety Inventory by Charles D. Spielberger (1977).

- Depression test Developed \& standardized by Prof. O. P. Mishra, Dr. V. B. Verma and Santosh Kumar, published by Agra Psychological cell Agra (U.P.). In this test consists of 32 items and 5 point scale and can be used on 18 years and above age group.

- Coping strategies questionnaire by A. K. Srivastava (2001).

\subsection{Procedure for Data Collection}

Proper rapport was established with the subjects and over view of the study was given to them. Later sports competition anxiety test questionnaire, general anxiety test questionnaire, depression questionnaire and coping strategies questionnaire was given to each subject and were asked to read the instructions given carefully. Thus after 60 minutes subjects hand over the questionnaire to investigator and were thanked by him therefore the data was collected in proper way.

\subsection{Statistical Methods}

Mean and Standard Deviation of each variable were calculated. For comparison of the variables between the groups statistical t-test was applied.

\section{RESUltS AND DISCUSSIONS}

The obtained results of the present study are as follows:

Table1. Significance of Mean Differences of Sports Completion Anxiety between West Bengal and Karnataka Athletes

\begin{tabular}{|c|c|c|c|c|c|c|c|c|}
\hline Variable & Group & N & Mean & S.D. & M.D. & S.ED & t value & Significant or not \\
\hline $\begin{array}{c}\text { Sports } \\
\text { competition } \\
\text { anxiety }\end{array}$ & $\begin{array}{c}\text { West } \\
\text { Bengal }\end{array}$ & 13 & 22.33 & 2.12 & 2.18 & 0.96 & $2.27 *$ & Significant \\
\cline { 2 - 5 } & Karnataka & 13 & 20.15 & 2.73 & & \\
\hline
\end{tabular}

Significant at 0.05 level, $d f=24$. (Table value of t at 0.05 level $=2.06$ for $d f 24$ )

International Journal of Sports and Physical Education (IJSPE) 
A Study on Anxiety Depression and Coping Strategies between West Bengal and Karnataka All India Inter University Male Athletes

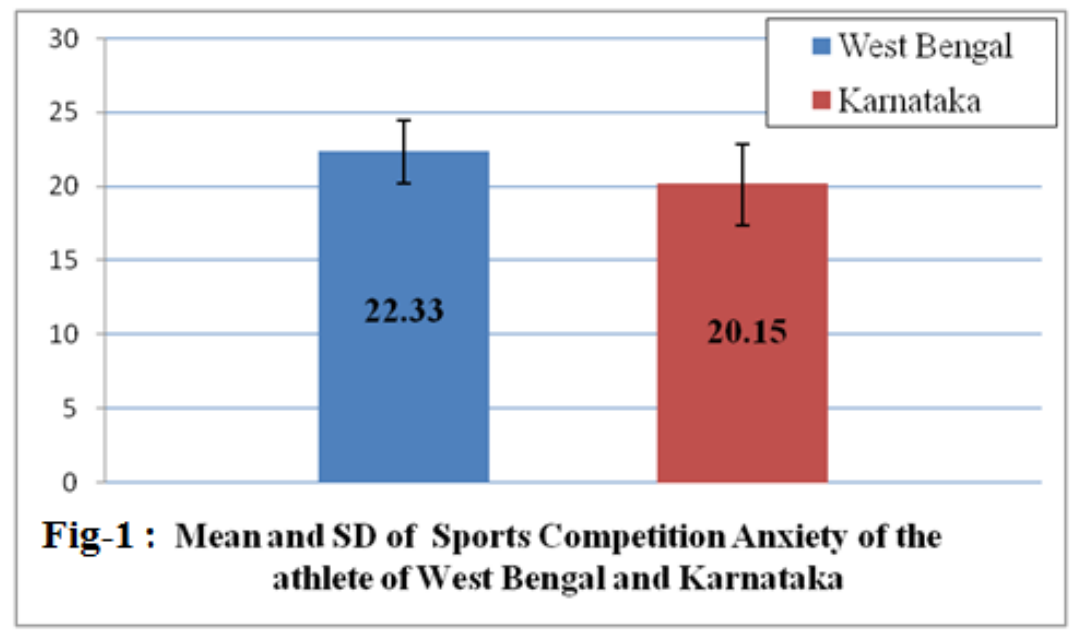

It is evident from table - 1 that mean value of all India athletes in West Bengal and all India athletes in Karnataka on the sports competition anxiety which were recorded 22.33 and 20.15 respectively . To find out the significant difference of the means ' $t$ ' test was calculated and found to be 2.27 .the $t$ value is statistically significant, because calculated t- value 2.27 was less than tabulated t- value (2.06). The mean and SD value of Sports Competition Anxiety have been shown in Fig-1.

Table2. Significance of Mean Differences of General Anxiety (State) between West Bengal and Karnataka Athletes

\begin{tabular}{|c|c|c|c|c|c|c|c|c|}
\hline Variable & Group & $\mathbf{N}$ & Mean & S.D. & M.D. & S.ED & t value & Significant or not \\
\hline General & Karnataka & 13 & 45.38 & 7.37 & \multirow[b]{2}{*}{0.54} & \multirow[b]{2}{*}{2.29} & \multirow[b]{2}{*}{0.23} & \multirow[b]{2}{*}{ Not significant } \\
\hline $\begin{array}{c}\text { Anxiety (State) } \\
\text { Y1 }\end{array}$ & $\begin{array}{l}\text { West } \\
\text { Bengal }\end{array}$ & 13 & 44.85 & 3.76 & & & & \\
\hline
\end{tabular}

Not Significant at 0.05 level, $d f=24$. (Table value of t at 0.05 level $=2.06$ for $d f 24)$

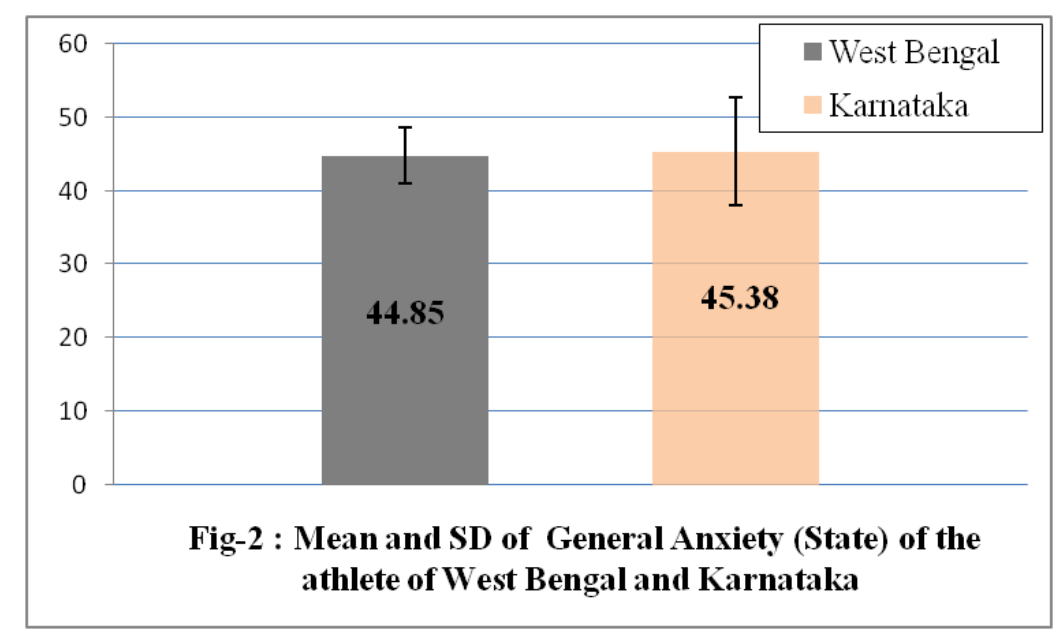

It is evident from table -2 that mean value of all India athletes in West Bengal and all India athletes in Karnataka on the state anxiety which were recorded 45.38 and 44.85 respectively. To find out the significant difference of the means $t$ test was calculated and found to be 0.23 . The $t$ value is not statistically significant, because calculated $t$ - value 0.23 was less than tabulated $t$ - value (2.06). The mean and SD value of General Anxiety (State) have been shown in Fig-2.

Table3. Significance of Mean Differences of General Anxiety (Trait) between West Bengal and Karnataka Athletes

\begin{tabular}{|c|c|c|c|c|c|c|c|c|}
\hline Variable & Group & $\mathbf{N}$ & Mean & S.D. & M.D. & S.ED & t value & Significant or not \\
\hline $\begin{array}{c}\text { General } \\
\text { Anxiety (Trait) }\end{array}$ & $\begin{array}{c}\text { West } \\
\text { Bengal }\end{array}$ & 13 & 46.77 & 2.35 & \multirow[t]{2}{*}{3.38} & \multirow[t]{2}{*}{1.63} & \multirow[t]{2}{*}{$2.07 *$} & \multirow[t]{2}{*}{ significant } \\
\hline Y2 & Karnataka & 13 & 43.38 & 5.39 & & & & \\
\hline
\end{tabular}

Significant at 0.05 level, $d f=24$. (Table value of $t$ at 0.05 level $=2.06$ for $d f 24$ ) 


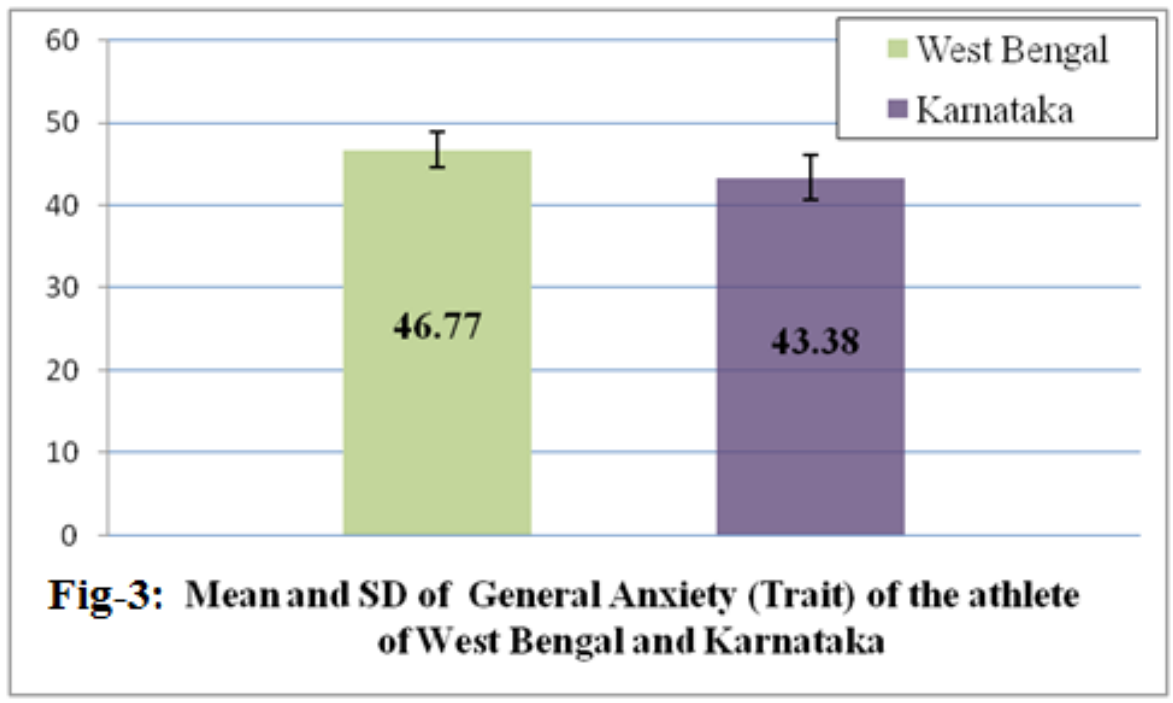

It is evident from table -3 that mean value of all India athletes in West Bengal and all India athletes in Karnataka on trait anxiety which were recorded 46.77 and 43.38 respectively. To find out the significant difference of means $t$ test was calculated and found to be 2.1 .the $t$ value is not statistically significant because calculated t- value 2, 1 was less than tabulated t- value (2.06). The mean and SD value of General Anxiety (Trait) have been shown in Fig-3.

Table4. Significance of Mean Differences of Depression between West Bengal and Karnataka Athletes

\begin{tabular}{|c|c|c|c|c|c|c|c|c|}
\hline Variable & Group & N & Mean & S.D. & M.D. & S.ED & t value & Significant or not \\
\hline \multirow{2}{*}{ Depression } & West Bengal & 13 & 82.69 & 12.43 & \multirow{2}{*}{2.77} & 5.66 & 0.49 & \multirow{2}{*}{ Not significant } \\
\cline { 2 - 7 } & Karnataka & 13 & 79.92 & 16.21 & & & \\
\hline
\end{tabular}

Not Significant at 0.05 level, $d f=24$. (Table value of $t$ at 0.05 level $=2.06$ for $d f 24$ )

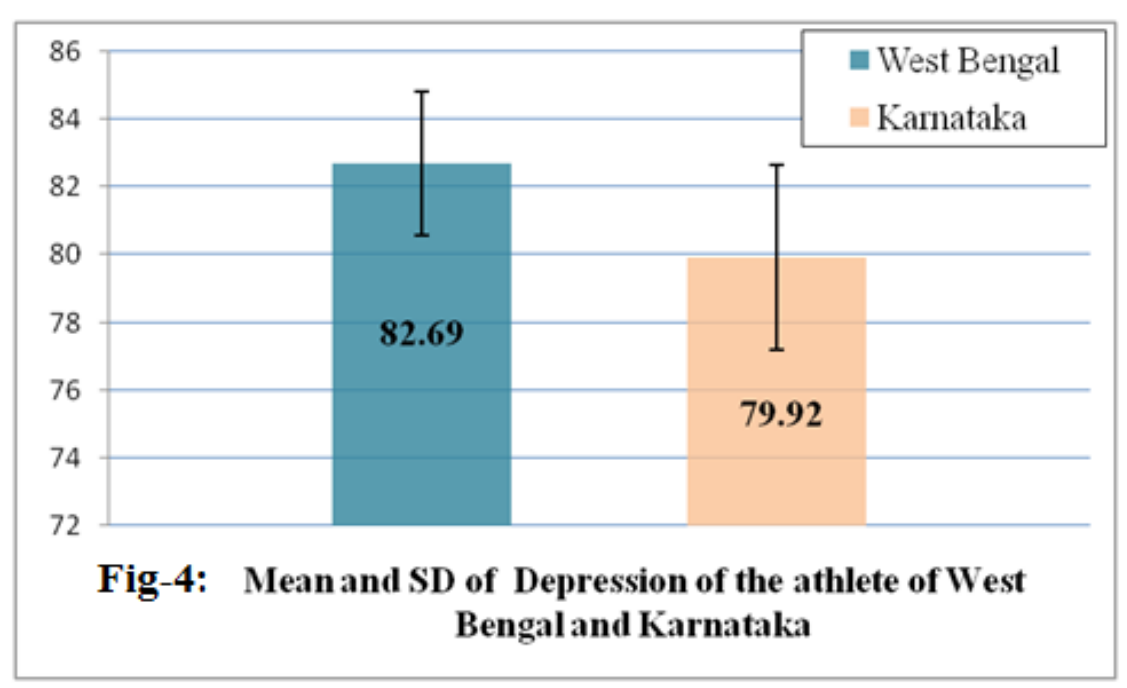

It is evident from table -4 that mean value of all India athletes in West Bengal and all India athletics player in Karnataka on depression which were recorded 82.69 and 79.92 respectively. To find out the significant difference of means $t$ test was calculated and found to be 0.49 . The $t$ value is not statistically significant, because calculated $\mathrm{t}$ - value 0.49 was less than tabulated $\mathrm{t}$-value (2.06). The mean and SD value of depression have been shown in Fig-4.

Table5. Significance of Mean Differences of Coping Strategies between West Bengal and Karnataka Athletes

\begin{tabular}{|c|c|c|c|c|c|c|c|c|}
\hline Variable & Group & N & Mean & S.D. & M.D. & S.ED & t value & Significant or not \\
\hline $\begin{array}{c}\text { Coping } \\
\text { strategies }\end{array}$ & $\begin{array}{c}\text { West } \\
\text { Bengal }\end{array}$ & 13 & 98.61 & 12.03 & 11.23 & 6.27 & 1.79 & Not significant \\
\cline { 2 - 8 } & Karnataka & 13 & 87.38 & 19.16 & & & & \\
\hline
\end{tabular}

Not Significant at 0.05 level, $d f=24$. (Table value of t at 0.05 level $=2.06$ for $d f 24$ ) 


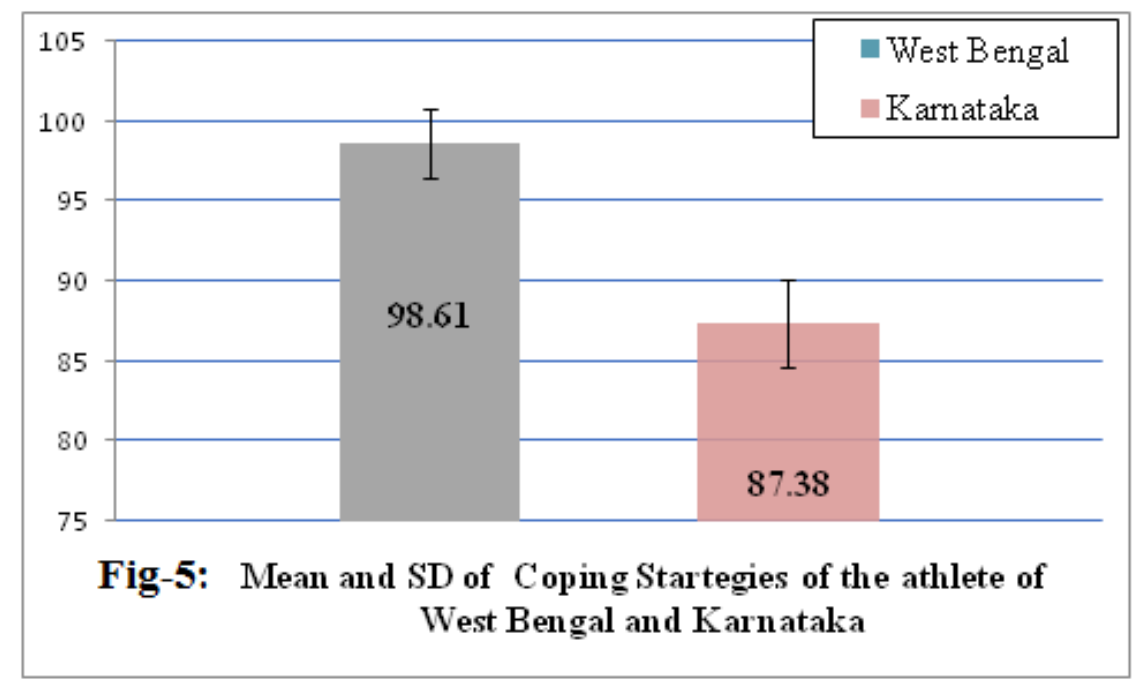

It is evident from table - 5 that mean value of all India athletes in West Bengal and all India athletes in Karnataka on coping strategies which were recorded 98.61 and 87.38 respectively. To find out the significant difference of means $t$ test was calculated and found to be 1.79 . The $t$-value is not statistically significant because calculated $t$ - value 1.79 was less than tabulated $t$ - value (2.88). The mean and SD value of coping strategies have been shown in Fig-5.

Anxiety, depression and coping strategies play a paramount role in sports. It is the challenge in sports participation which produces anxiety. How an athlete handles the anxiety determines how successful he would be. Anxiety may be a positive motivating force or it may interfere with successful performance in sports events. The degree of anxiety also varies with a number of different conditions. Anxiety is likely to be greater in higher competitive sports than in relatively non competitive sports, because in the competitive sports, participants are expected to win a great demands are made up on them to succeed. Douglas et al (2006) stated that the major sources of depression include: fear of failure, thinking too much on what people may say about the performance, and lack of confidence.

The results of present study demonstrated that significant difference was found between mean scores of sports competition anxiety between Sports Completion Anxiety between West Bengal and Karnataka Athletes.

The results of present study demonstrated that significant difference was also found between mean scores of General anxiety (trait) between West Bengal and Karnataka Athletes.

But in case of General anxiety (state), Coping Strategies and Depression no significant difference were found between the male athletes of West Bengal and Karnataka. For all these cases obtained tvalue was insignificant at 0.05 level of confidence. It indicates that there was no significant difference between the mean scores of male players and male players in respect to sports competitive anxiety, general anxiety and coping strategies for both the groups.

\section{CONClusion}

- West Bengal all India male athletes are found significantly higher in case of sports competition anxiety than Karnataka all India male athletes.

- West Bengal all India male athletes are found significantly higher in case of general trait anxiety (Y2) than Karnataka all India male athletes.

- No difference was found between West Bengal and Karnataka all India male athletes in case general state anxiety (Y1).

- No difference was found between West Bengal and Karnataka all India male athletes in case depression.

- No difference was found between West Bengal and Karnataka all India male athletes in terms of coping strategies. 


\section{REFERENCES}

[1] Ali S R et al., (2014) Source of stressors and emotional disturbances among undergraduate science in Malaysia. International Journal of Medical Research \& Health Science. 3(2):401-410

[2] Barimani. A Comparing and Examining the Amount of Aggression between the Athletic and Non athletic Students, World Applied Sciences. Journal, ISSN 1818- 4952, IDOSI Publications, 2009; 6(4):460-463.

[3] Barlow, D. H. (2002).Unraveling the mysteries of anxiety and its disorders from the perspective of emotion theory. American Psychologist, 55, 1247-1263. http://dx.doi.org/10.1037/0003-66X.55.11.1247

[4] Black dog institution (2012) Depression in adolescents \& young people http://www.blackdoginstitute .org.au/docs/DepressioninAdolescentsandYoungPeople.pdf

[5] Bourne, E. J. (2005). The anxiety \& phobia workbook (4th Ed.). Oakland, CA: New Harbinger Publications.

[6] Cox Richard X. Sports Psychology concept and applications, Fifth edition. McGraw Hill United States, 2002.

[7] Eva A. Vadoa et al. The relationship between competitive anxiety and imagery use, Journal of Applied Sport Psychology 1991; 9:2.

[8] Firth J. (1986) Levels and sources of stress in medical students.Br Med J (Clin Res Ed). 292(6529): 11771180.

[9] Garrett, Hanery E. Statistics in Psychology and Education", Paragon International Publisher, New Delhi, 2004. 5 Hannon B, Fitzgerald P. Anxiety and performance in elite non-professional athletes. Journal of international medicine and sports 2006; 99(8):238-240.

[10] Joachim Stoeber et al., Perfectionism and competitive anxiety in athletes: Differentiating striving for perfection and negative reactions to imperfection" Personality and Individual Differences, page no, 2006, 959-969.

[11] Kring AM, et al. (2011) Abnormal Psychology. New Delhi: Black Publication, 2011; p 216

[12] Ohman A (2000).Fear and anxiety: Evolutionary, cognitive, and clinical perspectives. In M. Lewis, \& J. M. Haviland-Jones (Eds.) Handbook of emotions. New York, NY: The Guilford Press. 537-593

[13] Pyari D. A. (2015) Comparative Study of anxiety and depression among medical and engineering student. American Research Thoughts. 1(9):2067-2078

[14] Ruffin, P. (2007). A Real Fear: It's More Than Stage Fright, Math Anxiety can Derail Academic or Professional Success, But Some Scholars are Working to Help Students Get over It. Diverse Issues in Higher Education. Findarticle.com (online) http://findarticles.com/p/articles/mi_m0WMX/is_2_24/ai_ n18744928/

[15] Sabate E. (2004). Depression in young people and the elderly. In priority medicines for Europe and the world. NY:WHO 6.15-4 6.15-6.32

[16] Singh I and Jha A. (2013) Anxiety, optimism and academic achievement among students of private medical and engineering colleges: A Comparative Study. Journal of Educational and Development Psychology. 3(1)222-233.

[17] Supe AN. (1998) A study of stress in medical students at Seth G.S. Medical College. J Postgrad Med. 44(1): $1-6$.

Citation: Dr. Sandip Sankar Ghosh, Mr. Anantarup Sen Sarma. “A Study on Anxiety Depression and Coping Strategies between West Bengal and Karnataka All India Inter University Male Athletes" International Journal of Sports and Physical Education (IJSPE), vol 5, no.1, 2019, pp. 1-6. doi: http://dx.doi.org/ 10.20431/2454-6380.0501001.

Copyright: (C) 2019 Authors. This is an open-access article distributed under the terms of the Creative Commons Attribution License, which permits unrestricted use, distribution, and reproduction in any medium, provided the original author and source are credited. 